\title{
High arsenic contamination in drinking water hand-pumps in Khap Tola, West Champaran, Bihar, India
}

\author{
Siddharth Bhatia ${ }^{1 *}$, Guru Balamurugan ${ }^{2}$ and Annu Baranwal ${ }^{3}$ \\ Disaster Management, Tata Institute of Social Sciences, Mumbai, India \\ 2 Jamsetji Tata Centre for Disaster Management, Tata Institute of Social Sciences, Mumbai, India \\ ${ }^{3}$ Environmental Health Resource Hub, Tata Institute of Social Sciences, Mumbai, India
}

\section{Edited by:}

Khwaja M. Sultanul Aziz,

Bangladesh Academy of Sciences,

Bangladesh

\section{Reviewed by:}

Roshanak Rezaei Kalantary, Iran University of Medical Sciences, Iran Munawar Sultana, University of

Dhaka, Bangladesh

${ }^{*}$ Correspondence:

Siddharth Bhatia, Jamsetji Tata Centre for Disaster Management, Tata Institute of Social Sciences, Malti and Jal A. D. Naoroji Campus (Annex), PO Box No. 8313, Deonar, Mumbai 400 088, India

e-mail: bhatiasidd@gmail.com
This study tests the drinking water supply of a marginalized village community of Khap Tola in the state of Bihar, a state in Northern India. Based on hand pump drinking water sample testing and analysis, we found that there was high levels of arsenic (maximum value being $397 \mathrm{ppb}$ ), in excess of the WHO limits of 10ppb. Analysis showed $57 \%$ of the samples from private hand-pumps in the shallow aquifer zone of $15-35 \mathrm{~m}$ have arsenic greater than $200 \mathrm{ppb}$. Using GIS overlay analysis technique it was calculated that $25 \%$ of the residential area in the village is under high risk of arsenic contamination. Further using USEPA guidelines, it was calculated that children age group 5-10 years are under high risk of getting cancer. The Hazard Quotient calculated for 21 children taken for study, indicated that children may have adverse non-carcinogenic health impacts, in the future, with continued exposure. Since the area adds a new arsenic contaminated place in India, further geochemical analysis and health assessment needs to be done in this district of West Champaran in, Bihar.

Keywords: arsenic contamination, hand-pumps, West Champaran, groundwater, GIS overlay analysis, hazard quotient

\section{INTRODUCTION}

Water hand-pumps were installed in the alluvium plains of Ganges and Brahmaputra of Northern India (Chen and Ahsan, 2004), as a public health measure to combat diarrheal and water borne diseases associated with drinking water from open wells and streams. Water from Open wells and streams were more prone to contamination with faecal micro-organisms. This problem was overcome by the introduction of the sealed hand pumps. The last 20-30 years, there has seen an increase use of groundwater for drinking purposes in rural areas (Jakariya et al., 2003). As the government hand-pumps became popular, due to their lowcost and easy accessibility and use; a number of private providers began to install hand-pumps to provide households with drinking water (Smith et al., 2003).

The private hand-pumps were not as deep as the government installed hand pumps. These hand-pumps brought with them the risk of arsenic contamination, which has been declared as one of the key environmental health problem of the 21st century (Christen, 2001). The first case of arsenic poisoning was detected in 1983 in Calcutta, West Bengal, India (Mazumdar, 2008). Since then a number of areas have been identified in different districts of West Bengal, Assam, Bihar, and Uttar Pradesh, which are states in north and eastern India (Kumar et al., 2009).

While arsenic, has been naturally present in groundwater for thousands of years; the kinetics of release from sediments and the residence time plays an important role increasing the arsenic concentrations in certain aquifers, especially in the younger alluvium flood plains of the Ganges (Stute et al., 2007).
WHO has classified arsenic as one of 10 chemicals of public health concern (WHO, 2010). A number of health effects, like skin lesions, peripheral neuropathy, gastrointestinal symptoms, diabetes, renal system effects, cardiovascular disease, and cancer have been linked to arsenic contamination. However, the signs and symptoms can take years to develop depending on the level of exposure (Hindmarsh et al., 2002; WHO, 2010). The vulnerable groups are pregnant women and infants, who are at higher risk of arsenic exposure, as arsenic is known to pass through the placenta (U.S. EPA, 2007). Children are at higher risk of arsenic poisoning, as the symptoms are usually undetectable in the early stages (Singh and Ghosh, 2012). The early symptoms go unnoticed or are ignored, due to lack of education and awareness in the context of low socio-economic status and poor medical facilities, in these areas (Safiuddin and Karim, 2001). Further, the high prevalence of malnutrition and protein deficiency among children makes them more vulnerable to arsenic poisoning (WHO, 2010). The International Agency for Research and Cancer (IARC) first evaluated the health effects of arsenic in 1973 and concluded that it causes cancer through drinking water (IARC, 1973). The same conclusions were drawn in the second evaluation performed in 1980 by IARC. In the more recent studies conducted by IARC, inorganic arsenic was classified as Group A human carcinogen which can cause cancer of the urinary bladder, lung, skin and possibly also kidney and liver (IARC, 2004). The earliest signs of toxicity from chronic exposure to arsenic in drinking water in humans are pigmentation changes, which are known as arsenicosis (IARC, 2004). The latency period is usually $5-10$ years of consumption of 
arsenic-contaminated water greater than the unsafe levels (NRC, 2001).

Based on this evidence and the widespread arsenic cases around the world, WHO revised the drinking water guidelines in 1993, with safe limits for arsenic in drinking water was reduced from 50 to $10 \mathrm{ppb}$, making more stringent acceptable limits in the drinking water standards. However, in India the old acceptable limits of 50ppb are being followed by Bureau of Indian Standards (BIS) (Smedley and Kinniburgh, 2002).

The Gangetic belt in Bihar has been researched for arsenic contamination, both in terms of its release mechanism in ground water and public health concerns. However, there are remote villages, like the study area (Khap Tola) which exclusively use hand-pumps as their only source of drinking water. The aim of this study was to quantify arsenic contamination of the drinking water of Khap Tola residents, and used GIS overlay techniques to map the population at risk, by identifying the hand-pumps, which were the only source of drinking water.

\section{METHODS \\ STUDY AREA}

West Champaran district lies between $26^{\circ} 16^{\prime} \mathrm{N}$ and $27^{\circ} 31^{\prime} \mathrm{N}$; $83^{\circ} 50^{\prime}$ and $85^{\circ} 18^{\prime} \mathrm{E}$ in the north-western part of Bihar sharing its border with hilly region of Nepal on the north and the Padrauna and Deoria district of Uttar Pradesh on the west. The study area of Khap Tola was chosen for sample testing, as it had been identified as a high-risk area in previous studies done by Megh Pyne Abhiyan (MPA), a NGO working in the flood affected districts of North Bihar. Total population of the Khap Tola was 916 with 138 households spread across the village. There are a total of 85 hand-pumps in the village with 20 governments installed and 65 private. The wells in the village were not used anymore as hand-pumps were nearer and more convenient to use. A cluster of the marginalized and caste-discriminated residents was chosen for drinking water sampling. In this cluster, there are a total of 20 hand-pumps with 6 government and 14 installed privately. The location of Khap Tola is shown in Figure 1.

\section{SAMPLE COLLECTION AND TESTING}

Water samples from all 20 hand-pumps in this cluster were tested for the presence of arsenic in drinking water. Standard water testing methodology was followed and the samples were acidified with two drops of HCL to maintain a $\mathrm{pH}<2$. The samples were tested in the Department of Environment and Water Management, A.N. College, Patna using Atomic Absorption Spectrophotometer (AAS) in the laboratory.

\section{GIS OVERLAY ANALYSIS}

To study the distribution of arsenic in the village, a Land Use /Land Cover (LU/LC) Map using National Remote Sensing Agency (NRSA) classification was prepared in Arc GIS software for the village to get idea of land use and settlements. Contour map for arsenic distribution was prepared using the Surfer software from the values of arsenic of 20 samples tested. The values were categorized into five categories based on the BIS limits. These are "Safe (<50ppb)," "High (50-100 ppb)," "Very High
(100-150 ppb)," "Severely High (150-200 ppb)" and "Extremely High (>200ppb)." The overlay of the two maps was done to get the vulnerability of the population drinking water from the hand-pumps in Khap Tola.

\section{ARSENIC EXPOSURE AND TOTAL DOSE INTAKE CALCULATIONS}

United States Environmental Protection Agency has classified inorganic arsenic (As) as Group A human carcinogen (U.S. EPA, 2007). The USEPA guidelines were used to estimate arsenic intake among children of age group 5-10 years. Average Total Dose (ATD), Chronic Daily Intake (CDI), Cancer Risk (CR) and Hazard Quotient (HQ) were calculated (Liu et al., 2009; Muhammad et al., 2010; Singh and Ghosh, 2012).

An open- and closed-ended questionnaire was asked to the mothers of these children. The questionnaire included questions like: (A) How much water do the children drink per day? (B) What is the volume of vessel they use for drinking water? (C) What is the number of times they drink water every day? Village people usually use a glass or a big jar (lota) to drink water. The volume of the glass or jar varies between 500 and $1500 \mathrm{~mL}$. The objective was to know the approximate average per capita consumption of water among children age group 5-10 years.

Convenient sampling was done from the cluster and 21 children ( $10 \%$ of the total population of Khap Tola) between the age group 5-10 years were taken for study.

\section{RESULTS}

\section{ARSENIC CONTAMINATION IN GROUNDWATER OF KHAP TOLA}

All the 20 samples taken from hand-pumps tested positive for the presence of arsenic with $100 \%(N=20)$ samples having aresnic> $10 p p b$ limit of WHO and $80 \%(N=20)$ of the samples having arsenic $>50 p p b$ limit of the BIS. The maximum value noted was $397 \mathrm{ppb}$, indicating high presence of arsenic in drinking water hand-pumps in Khap Tola.

There was found a correlation between the arsenic values and the depth of the hand-pump as shown in Figure 2. High values of arsenic are usually found in the $15-35 \mathrm{~m}$ zone and thereafter the values from deeper points are less.

Most of the hand-pumps in the study area are located in the shallow aquifer zone of $15-35 \mathrm{~m}$ with the average depth of the hand-pump being $22 \mathrm{~m}$, thus tapping the groundwater stored between the pore spaces of the silt and sand. Clay acts as a relatively impermeable layer with low hydraulic conductivity, thus trapping the water and forming the aquifer zones (Mukherjee et al., 2012). Since water in the area is easily available at an average depth of $3.4 \mathrm{~m}$, it is easier to dig in hand-pumps in the shallow depths of the aquifer. In the $15-35 \mathrm{~m}$ zone, $57 \%(N=14)$ of the samples from the private hand-pumps have arsenic $>200 \mathrm{ppb}$. Out of the 6 samples taken from government installed community hand-pumps, $50 \%$ had arsenic $<50 \mathrm{ppb}$. The average depth of these samples was $50 \mathrm{~m}$.

This confirms the presence of high levels of arsenic in the shallow aquifers of this cluster. The relatively easy access to the shallow aquifers as compared to the deeper ones through private handpumps makes the population more prone to consume arsenic contaminated water, with no alternate sources of drinking water, as the community wells are not being used anymore. 
India showing state of Bihar and West Champaran district
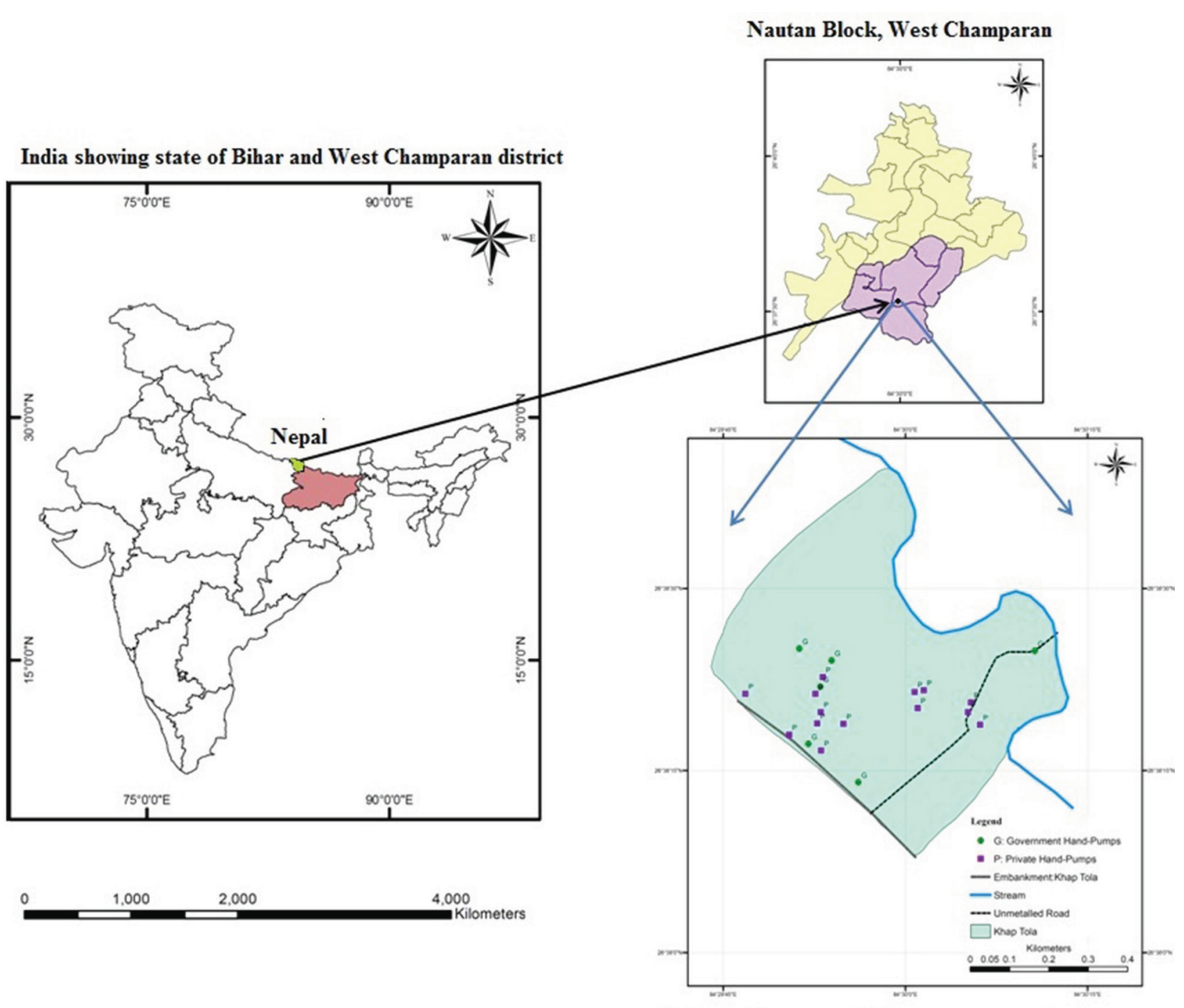

Khap Tola area with drinking water sample locations

FIGURE 1 | Map of study area showing the location of Khap Tola with drinking water sample locations. Khap Tola lies in Nautan block in West Champaran district, which is shown in the map. P and G denote Private and Government hand-pumps respectively.

\section{VULNERABILITY OF POPULATION IN RESIDENTIAL AREAS DRINKING ARSENIC CONTAMINATED WATER}

The GIS overlay analysis of the two maps of land use and arsenic values is shown in Figure 3. Total area of the village is around 14 $\mathrm{Ha}$ and the total area affected by arsenic contamination comes out to be around $3.5 \mathrm{Ha}$ in the residential area. Thus, $25 \%$ of the area in the village is under high risk of arsenic contamination which is the residential area and thus people drinking groundwater from these areas are highly vulnerable to the direct ingestion of arsenic through drinking water. Table 1 gives the arsenic contamination in the settlement of Khap Tola.

It is clear from Figure 3 that almost $50 \%$ of the samples lie in the severely high (150-200 ppm) and extremely high (>200 ppm) category. All these samples are private hand-pumps as indicated by notation " $\mathrm{P}$ " in the figure.

\section{TOTAL ARSENIC INTAKE IN CHILDREN OF AGE GROUP 5-10 YEARS}

The inorganic arsenic soluble in groundwater is highly toxic and ingestion of toxic doses leads to chronic poisoning symptoms, disturbances of cardiovascular and nervous system functions.

Long-term exposure due to drinking of Arsenic contaminated water is related to increased risks of cancer. Children are at higher risk of arsenic contamination.

\section{Average total dose (ATD)}

It is the product of contaminant concentration in $\mathrm{mg} / \mathrm{L}$ and intake rate of water in $\mathrm{L}$ :

$$
A T D(m g)=A s w \times I R
$$

where; Asw = Arsenic contamination of water $(\mathrm{mg} / \mathrm{L})$; IR $=$ Water Ingestion rate (L/day). 


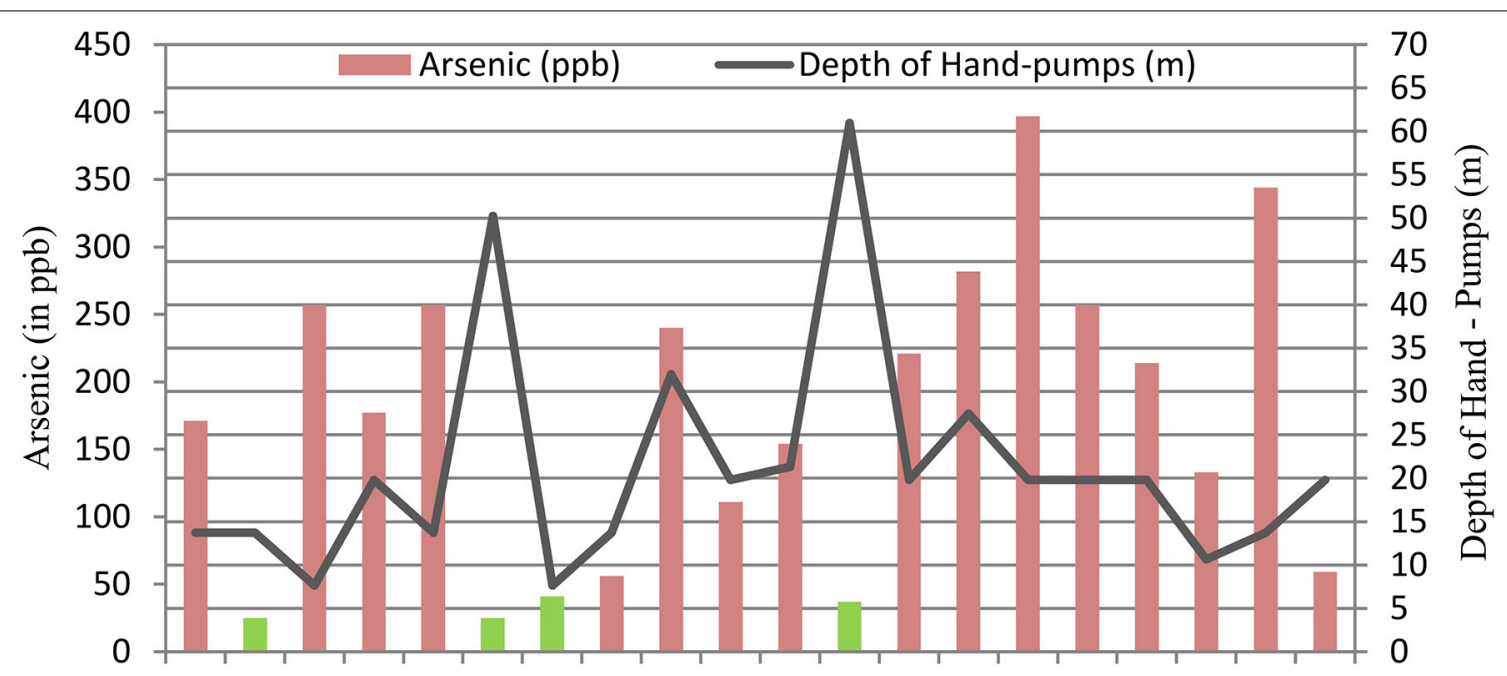

$\begin{array}{llllllllllllllllllll}1 & 2 & 3 & 4 & 5 & 6 & 7 & 8 & 9 & 10 & 11 & 12 & 13 & 14 & 15 & 16 & 17 & 18 & 19 & 20\end{array}$

Sample Number

FIGURE 2 | Relation between arsenic values (ppb) and depth of hand-pumps $(\mathbf{m})$ for drinking water sample testing and analysis. $57 \%$ of the private hand-pumps in the 15-35 m zone have arsenic greater than 200 ppb. The two peaks in depth curve are from government hand-pumps (sample number 6 and 12) having arsenic less than 50 ppb. This clearly indicates high arsenic contamination in the shallow aquifer zone of $15-35 \mathrm{~m}$.

\section{Chronic daily intake (CDI)}

It is derived by dividing total dose by body weight of person by using the formula:

$$
\text { CDI }(m g / K g \text { day })=\text { Total Dose }(m g) / \text { Bodyweight }(K g)
$$

\section{Cancer risk (CR)}

Lifetime cancer risk assessment through oral ingestion of arsenic was estimated by the following equation:

$$
\text { Cancer Risk }=\text { CDI } \times \text { Potency Factor }(P F)
$$

where; PF (oral route) for arsenic is $1.5(\mathrm{mg} / \mathrm{Kg} / \text { day })^{-1}$ (Established by USEPA's Integrated Risk Information SystemIRIS) If the value of Cancer Risk (CR) is between $10^{-4}$ and $10^{-6}$, it is believed that the cancer risk is acceptable.

The Values of ATD, CDI, CR, and HQ calculated for 21 children is shown in Table 2.

The results of CDI and CR calculated using above formulas are shown in Figure 4, plotted with each child between 5 and 10 years taken for sample study. CDI is the chronic intake of arsenic through drinking water among children of age group 5-10 years. The minimum value observed for CR is 0.0043 which is much higher than $10^{-4}$ indicating that the CR is not acceptable. It represents high risk to children as is shown in the Cancer Risk (CR) values indicating higher the concentration of arsenic ingested through drinking water, higher the chances of getting cancer over the years.

\section{Hazard quotient (HO or HI)}

Hazard quotient or hazard index is the index of non-carcinogenic toxicity of a substance, in this case arsenic in drinking water (unit less). It can be calculated by the following formula:

$$
H Q \text { or } H I=C D I / R f D
$$

where; RfD is the reference dose for As $(\mathrm{mg} / \mathrm{Kg} \mathrm{d})$, i.e., $3 \times 10^{-4}$.

A Hazard Quotient (HQ) less than 1 is considered to infer no significance risk of non-carcinogenic effects.

The results of the hazard quotient among children age group taken for study are shown in Figure 5. Results show that because of the consumption of arsenic-contaminated drinking water, the area had HQs ranging from 9 to 235 for the 21 children in the age group 5-10 years. The lower and the upper end of the range both are greater than 1, indicating that the children are at future risk of cancer, and are more likely to have significant adverse non-carcinogenic health impacts.

\section{DISCUSSIONS}

Arsenic contamination has been a matter of serious concern in the last three decades. Since the first reported case of arsenic in India in 1983 in West Bengal, there has been a lot of research carried out in India and Bangladesh by different scientists and national/international agencies. In Bihar, the first case was reported in 2002 in Semria Ojha Patti village in Bhojpur district (Mukherjee et al., 2006). The Ganga belt corridor has been a focus area of the state government and Public Health and Engineering Department (PHED) for various mitigation measures. As part of studying the arsenic contamination, one of the blocks, named Nautan was selected. After initial sampling from 6 panchayats and analysis at department of Earth Sciences, IIT Mumbai, suggested that one of the villages Khap Tola had a high arsenic contamination with 3 samples having arsenic greater 


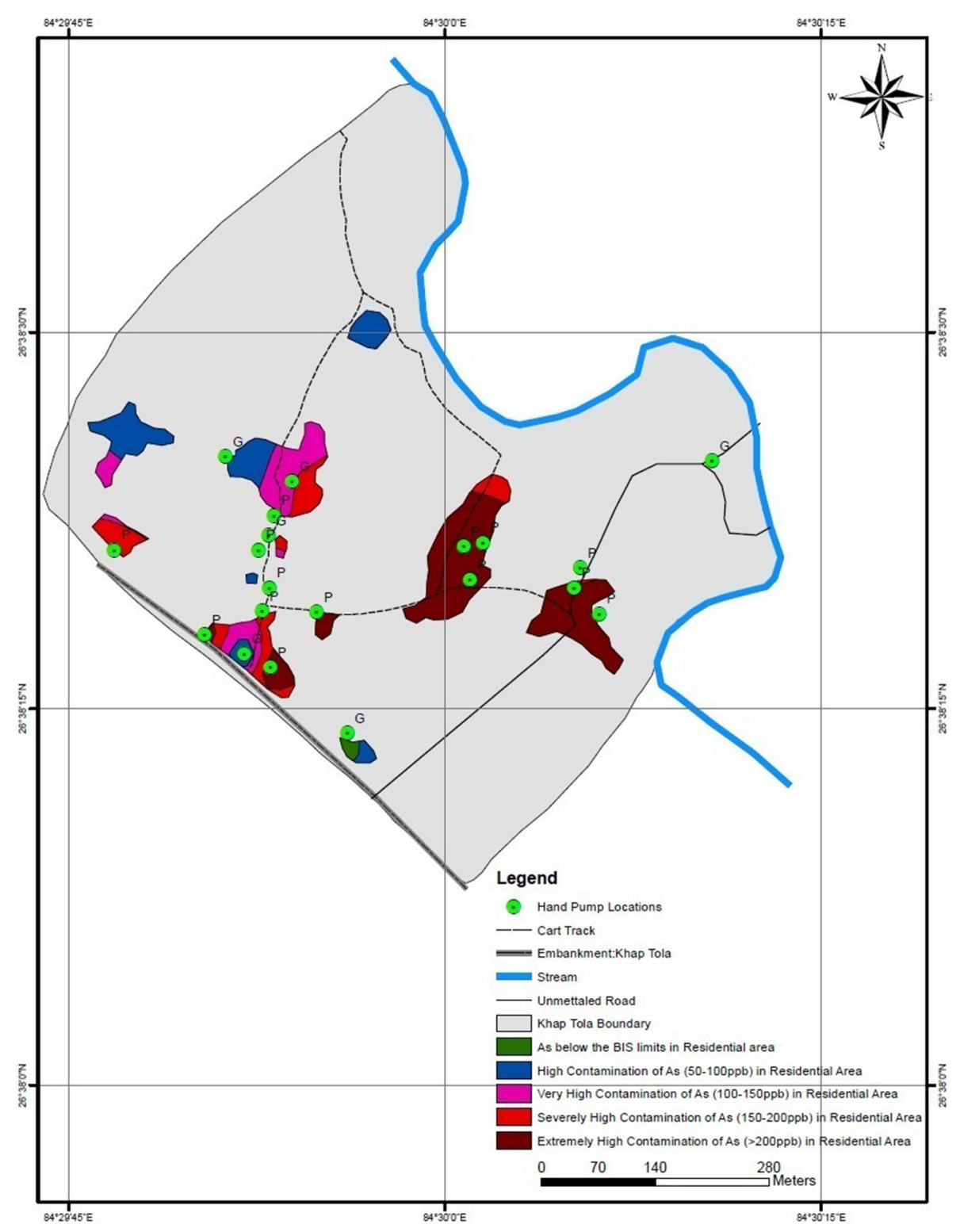

FIGURE 3 | GIS Overlay analysis of arsenic distribution in Khap Tola. The results show that maximum area of settlements 1.6 Hectares lies in the Extremely High (>200 ppb) zone indicating high arsenic toxicity in hand-pumps used for drinking water.

than $50 \mathrm{ppb}$, which was 40 times more than the WHO prescribed limits of $10 \mathrm{ppb}$. Analysis of samples from drinking water hand-pumps in the study area, revealed that more than $50 \%$ of the hand-pumps having arsenic greater than $200 \mathrm{ppb}$ were private owned and lying in the shallow aquifer zone of $15-35 \mathrm{~m}$. This finding is similar to other studies in West Bengal and Bangladesh (Smith et al., 2003; Ahmed et al., 2011). Though the government installed hand-pumps for people to get clean pathogen-free drinking water, it had a disadvantage of subjecting the population to arsenic contaminated water. Further as the shallow hand-pumps were cheaper, many households installed these hand-pumps in their homes. Since these hand-pumps are the exclusive and only source of drinking water for the population, the problem has been magnified. This has been reflected in previous studies in similar areas (Frisbie et al., 2002; Ahmed and Halder, 2011).

The population in the village is under high risk which was calculated using the GIS overlay technique. Spatial distribution of arsenic is an important indicator for calculating the vulnerability of population exposed to arsenic in drinking water. GIS studies have been used for mapping the arsenic contamination in India and Bangladesh (Shams and Rahman, 2010; Buragohain and Sarma, 2012). Also since children are the most vulnerable group as has been shown by various studies (Smith et al., 2006; Mazumder, 2007) and due to poor nutrition and socio-economic conditions in the village, focus was on children age group 5-10 
years in the study. Using USEPA guidelines, it was estimated that children are under high risk of developing significant carcinogenic and non-carcinogenic effects. They are under risk from arsenic toxicity due to the higher arsenic consumption in children on a body-weight basis as was seen in this study of 21 children between 5 and 10 years with the average daily intake value of $0.03 \mathrm{mg} / \mathrm{kg} / \mathrm{day}$ far greater than the Tolerable Daily Intake (TDI) of $0.001 \mathrm{mg} / \mathrm{kg} /$ day given by the report on human-toxicological maximum permissible risk levels (Baars et al., 2001). This has been confirmed in a study where almost $90 \%$ of the children less than 11 years, living in arsenic affected villages in West Bengal have shown elevated levels of arsenic in hair and nails (Mukherjee et al., 2006). There is no known treatment available for arsenic related diseases (Smith et al., 2000; Jakariya et al., 2003) and due to lack of medical facilities and health experts in the village, the only way to avoid arsenic exposure is by providing safe drinking water. However, the first priority still remains in identifying the contaminated water sources in rural villages, especially the remote

Table 1 | Area under arsenic contamination (in Hectares) in Khap Tola.

\begin{tabular}{llc}
\hline S. No. & Category & Area (Ha) \\
\hline 1 & $\begin{array}{l}\text { Arsenic below the BIS limit }(<50 \mathrm{ppb}) \\
\text { High contamination of arsenic }(50-100 \mathrm{ppb}) \text { in the }\end{array}$ & 0.03 \\
& $\begin{array}{l}\text { residential area } \\
\text { Very high contamination of arsenic }(100-150 \mathrm{ppb})\end{array}$ & 0.62 \\
4 & $\begin{array}{l}\text { in the residential area } \\
\text { Severely high contamination of arsenic }(150-200\end{array}$ & 0.56 \\
& $\begin{array}{l}\text { ppb) in the residential area } \\
\text { Extremely high contamination of arsenic }(>200\end{array}$ & 1.59 \\
& ppb) in the residential area
\end{tabular}

areas where people are forced to drink arsenic contaminated water.

This study will be useful to initiate the process of further scientific testing and analysis of drinking water samples in West Champaran district thereby putting it in the arsenic affected regions of Bihar which has not yet been done by the PHED, Bihar as seen on their web portal of water quality (http://phed.bih.nic. in/WaterQuality.htm).

Further geochemical analysis and health assessment is needed in West Champaran area to study the arsenic release mechanism so that interventions to reduce contamination and the public health effects of arsenic contamination in the resource-limited and low socio-economic setting. Making people aware of the carcinogenic effects of arsenic remains the top priority in the villages; and there are organizations like the Megh Pyne Abhyian (MPA), an NGO which raises awareness about arsenic contamination among residents of North Bihar.

This study attempts to highlight the attention of various stakeholders and the government to the poor villages of West Champaran district for providing safe drinking water to the residents. Further research is needed in the vulnerable population groups of children and pregnant mothers to determine the Public Health effects of consuming arsenic contaminated water over the years.

\section{ACKNOWLEDGMENTS}

First of all, we would like to thank Mr. Eklavya Prasad, managing Trustee of Megh Pyne Abhiyan, Bihar, for giving his full support and time to carry out this research. He has always shown faith for pursuing this research. We would also like to

\begin{tabular}{|c|c|c|c|c|c|c|c|c|c|}
\hline 1 & 5 & $M$ & 11 & 2 & 171 & 0.3420 & 0.031 & 0.047 & 104 \\
\hline 2 & 6 & $M$ & 12 & 2.5 & 171 & 0.4275 & 0.035 & 0.053 & 119 \\
\hline 3 & 10 & $M$ & 22 & 2.5 & 25 & 0.0625 & 0.002 & 0.004 & 9 \\
\hline 4 & 6 & $M$ & 16 & 2 & 257 & 0.5140 & 0.032 & 0.048 & 107 \\
\hline 7 & 6 & $\mathrm{~F}$ & 11 & 1 & 41 & 0.0410 & 0.003 & 0.006 & 12 \\
\hline 8 & 5 & $\mathrm{~F}$ & 10 & 1 & 56 & 0.0560 & 0.005 & 0.008 & 19 \\
\hline 9 & 7 & $M$ & 15 & 2 & 111 & 0.2220 & 0.014 & 0.022 & 49 \\
\hline 10 & 10 & $M$ & 25 & 3 & 154 & 0.4620 & 0.018 & 0.028 & 62 \\
\hline 11 & 8 & $M$ & 16 & 4 & 37 & 0.1480 & 0.009 & 0.014 & 31 \\
\hline 16 & 5 & $\mathrm{~F}$ & 10 & 2 & 257 & 0.5140 & 0.051 & 0.077 & 171 \\
\hline 17 & 7 & $M$ & 10 & 2 & 214 & 0.4280 & 0.042 & 0.064 & 143 \\
\hline 18 & 9 & $M$ & 12 & 2 & 214 & 0.4280 & 0.035 & 0.054 & 119 \\
\hline 19 & 5 & $M$ & 12 & 1 & 133 & 0.1330 & 0.011 & 0.017 & 37 \\
\hline 20 & 6 & $M$ & 16 & 2 & 344 & 0.6880 & 0.043 & 0.065 & 143 \\
\hline 21 & 9 & $\mathrm{~F}$ & 18 & 2 & 344 & 0.6880 & 0.038 & 0.057 & 127 \\
\hline
\end{tabular}




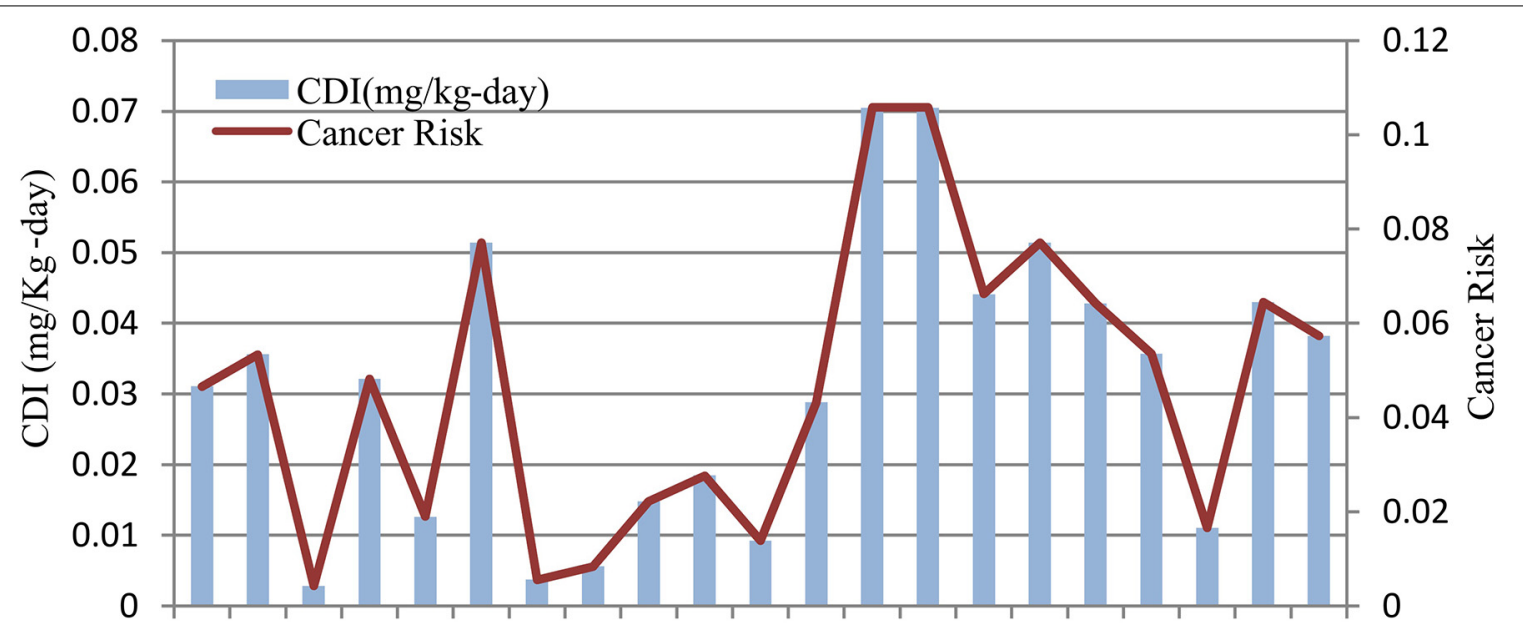

$\begin{array}{lllllllllllllllllllll}1 & 2 & 3 & 4 & 5 & 6 & 7 & 8 & 9 & 10 & 11 & 12 & 13 & 14 & 15 & 16 & 17 & 18 & 19 & 20 & 21\end{array}$

Children age group 5-10 years

FIGURE $\mathbf{4}$ | Chronic daily intake (mg/Kg-day) and cancer risk among children age group 5-10 years in Khap Tola. Higher the concentration of arsenic ingested through drinking water, higher the chances of getting cancer over the years.

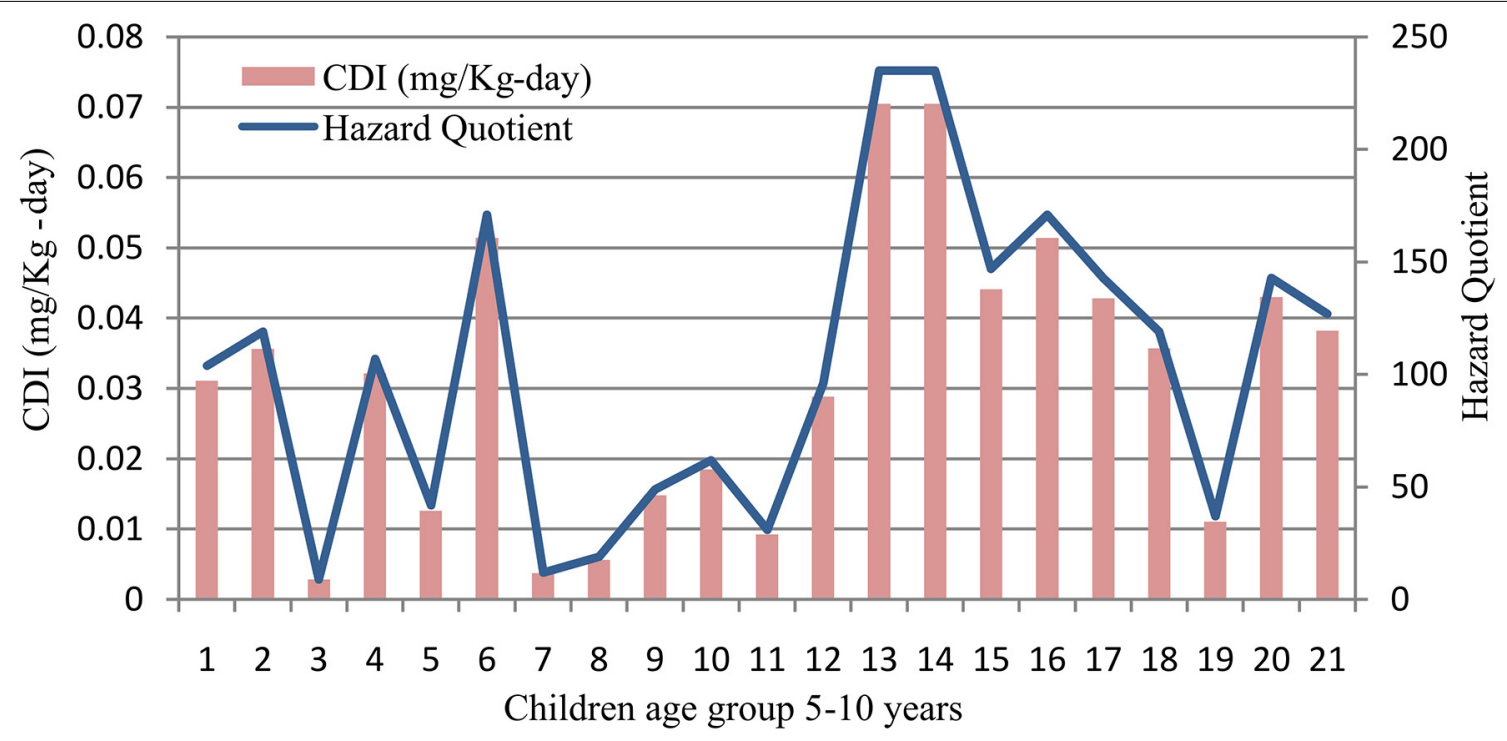

FIGURE $\mathbf{5}$ | Hazard Quotient (HO) among children age group 5-10 years in Khap Tola. The HQ range of 9-235 is both greater than 1, indicating that children might confront more significant adverse non-carcinogenic health impacts.

thank Dr. Nobhojit Roy, Environmental Health Resource Hub (EHRH), TISS, Mumbai and Elizabeth Weber of EHRH project for their support for writing down this paper and carrying on this study. We would also like to thank Dr. D. Chandrasekharam, Professor, Department of Earth Sciences, IIT, Mumbai, for giving us the valuable opportunity to work with him for our analysis at IIT. We would like to thank Dr. Ashok Ghosh, Professor In-charge at Dept. of Environment and Water Management; A.N. College, Patna for his belief in the research and thus accepting our request for testing samples at laboratory of A.N. College, Patna. His research work on arsenic and published papers, were a great help in developing a scientific approach toward the research. The research paper will remain incomplete without the mention of two very important persons $\mathrm{Mr}$. Vinay Kumar and Mr. Raj Kishore, Water Action NGO, West Champaran, who have helped us during our field visits and it is because of their enthusiasm and energy that the field sampling and interaction with the community was done in a smooth way. They have always been supportive arranging for our stay, food, and transportation in one of the remotest areas of Bihar. Their contribution is immense in bringing out this research paper. 


\section{REFERENCES}

Ahmed, A. A., Alam, M. J. B., and Ahmed, A. M. (2011). Evaluation of socioeconomic impact of arsenic contamination in Bangladesh. J. Toxicol. Environ. Health Sci. 3, 298-307. Available online at: http://www.academicjournals.org/ journal/JTEHS/article-abstract/6BA27C93491

Ahmed, S. I. M., and Halder, A. K. (2011). The socioeconomic impact of arsenic poisoning in Bangladesh. J. Toxicol. Environ. Health Sci. 3, 65-73. Available online at: http://www.academicjournals.org/article/article1379415914_ Shakeel\%20and\%20Amal.pdf

Baars, A. J., Theelen, R. M. C., Janseen, P. J. C. M., Hesse, J. M., van Apeldoorn, M. E., Meijerink, M. C. M., et al. (2001). Re-evaluation of human-toxicological maximum permissible risk levels. Res. Man Environ. RIVM Report: 711701025. 1-297. Available online at: http://rivm.openrepository.com/rivm/bitstream/ 10029/9662/1/711701025.pdf

Buragohain, M., and Sarma, H. P. (2012). A study on spatial distribution of arsenic in ground water samples of Dhemaji district of Assam, India by using arc view GIS software. Sci. Rev. Chem. Commun. 2, 7-11. Available online at: http://www.sadgurupublications.com/ContentPaper/2012/2_115_SRCC_2(1) 2012_P.pdf

Chen, Y., and Ahsan, H. (2004). Cancer burden from arsenic in drinking water in Bangladesh. Am. J. Public Health 94, 741-744. doi: 10.2105/AJPH.94.5.741

Christen, K. (2001). The arsenic threat worsens: in Vietnam and other developing countries, arsenic contamination of groundwaters is becoming the key environmental health problem of the 21st century. Environ. Sci. Technol. 35, 286A-291A. doi: 10.1021/es012394f

Frisbie, S. H., Richard, O., Maynard, D. M., and Sarkar, B. (2002). The concentrations of arsenic and other toxic elements in Bangladesh's drinking water. Environ. Health Perspect. 110, 1147-1153. doi: 10.1289/ehp.021101147

Hindmarsh, J. T., Abernethy, C. O., Peters, G. R., and McCurdy, R. F. (2002). "Environmental aspects of arsenic toxicity," in Heavy Metals in the Environment, 1st Edn., ed B. Sarkar (New York, NY: CRC Press), 217-229. doi: 10.1201/ 9780203909300.ch7

IARC. (1973). IARC Monographs on the Evaluation of Carcinogenic Risk of Chemicals to Man, Some Inorganic and Organomettalic Compounds. Vol. 2. Lyon: International Agency for Research on Cancer.

IARC. (2004). IARC Monographs on the Evaluation of Carcinogenic Risks to Humans; Some Drinking-water Disinfectants and Contaminants, Including Arsenic. Vol. 84. Lyon: International Agency for Research on Cancer.

Jakariya, M., Chowdhury, A. M. R., Hossain, Z., Rahman, M., Sarker, Q., Khan, R. I., et al. (2003). Sustainable community-based safe water options to mitigate the Bangladesh arsenic catastrophe - an experience from two upazilas. Curr. Sci. 85, 141-146. Available online at: http://www.iisc.ernet.in/ currsci/jul252003/141.pdf

Kumar, S., Jain, S. K., Shekhar, S., Sharma, V., and Central Ground Water Board. (2009). Arsenic in groundwater in India: an overview. Bhujal News 24, 1-9. Available online at: http://cgwb.gov.in/documents/Bhujal_News_24_2.pdf

Liu, Y., Zheng, B., Fu, Q., Meng, W., and Wang, Y. (2009). Risk assessment and management of arsenic in source water in China. J. Hazard. Mater. 170, 729-734. doi: 10.1016/j.jhazmat.2009.05.006

Mazumdar, D. N. G. (2008). Chronic arsenic toxicity \& human health. Indian J. Med. Res. 128, 436-447. Available online at: http://medind.nic.in/iby/ t08/i10/ibyt08i10p436.pdf

Mazumder, D. N. G. (2007). Effect of drinking arsenic contaminated water in children. Indian Pediatr. 44, 925-927. Available online at: http://www.indian pediatrics.net/dec2007/dec-925-927.htm

Muhammad, S., Tahir, M. S., and Khan, S. (2010). Arsenic health risk assessment in drinking water and source apportionment using multivariate statistical techniques in Kohistan Region, Northern Pakistan. Food Chem. Toxicol. 48, 2855-2864. doi: 10.1016/j.fct.2010.07.018

Mukherjee, A., Bridget, R. S., Alan, E. F., Dipankar, S., Ashok, G., Sunil, C., et al. (2012). Solute chemistry and arsenic fate in aquifers between the Himalayan foothills and Indian craton (Including Central Gangetic Plain): influence of geology and geomorphology. Geochim. et Cosmochim. Acta 90, 283-302. doi: 10.1016/j.gca.2012.05.015

Mukherjee, A., Sengupta, M. K., Hossain, M. A., Ahamed, S., Das, B., Nayak, B., et al. (2006). Arsenic contamination in groundwater: a global perspective with emphasis on the Asian Scenario. J. Health Popul. Nutr. 24, $142-163$.

NRC. (2001). "Arsenic in drinking, water 2001. Subcommittee to Update 1999 arsenic in drinking water report," in Arsenic in Drinking Water 2001 Update (Washingto, DC: National Academy Press), 24-74.

Safiuddin, M., and Karim, M. M. (2001). "Groundwater arsenic contamination in Bangladesh: causes, effects and remediation," in 1st IEB International Conference and 7th Annual Paper Meet (Chittagong: Institute of Engineers), 14.

Shams, S., and Rahman, S. M. S. (2010). "GIS based risk analysis for arsenic contamination : a case study of Chapai Nawabganj district in Bangladesh," in International Conference on Environmental Aspects of Bangladesh (ICEAB10) (Kitakyushu: University of Kitakyushu), 146-148.

Singh, S. K., and Ghosh, A. K. (2012). Health risk assessment due to groundwater arsenic contamination: children are at high risk. Hum. Ecol. Risk Assess. Int. J. 18, 751-766. doi: 10.1080/10807039.2012.688700

Smedley, P. L., and Kinniburgh, D. G. (2002). Source and Behaviour of Arsenic in Natural Waters Importance of Arsenic in Drinking Water. Oxon, UK: British Geological Survey.

Smith, A. H., Lingas, E. O., and Rahman, M. (2000). Contamination of drinking-water by arsenic in Bangladesh: a public health emergency. Bull. World Health Organ. 78, 1093-1103. Available online at: http://www.who.int/ bulletin/archives/78(9)1093.pdf

Smith, A. H., Marshall, G., Yuan, Y., Ferreccio, C., Liaw, J., von Ehrenstein, O., et al. (2006). Increased mortality from lung cancer and bronchiectasis in young adults after exposure to arsenic in utero and in early childhood. Environ. Health Perspect. 114, 1293-1296. doi: 10.1289/ehp.8832

Smith, M. M. H., Timir, H., Protap, C., Chakraborty, D. K., Xavier, S., and Smith, A. H. (2003). A dugwell program to provide arsenic-safe water in West Bengal, India: preliminary results. J. Environ. Sci. Health A Tox. Hazard. Subst. Environ. Eng. A38, 289-299. doi: 10.1081/ESE-120016895

Stute, M., Zheng, Y., Schlosser, P., Horneman, A., Dhar, R. K., Datta, S., et al. (2007). Hydrological control of as concentrations in Bangladesh groundwater. Water Resour. Res. 43, 1-11. doi: 10.1029/2005WR004499

U.S. EPA. (2007). Inorganic Arsenic; Chemical Summary. Vol. 23. Chicago: The U.S. EPA Region 5 Toxicity and Exposure Assessment for Children's Health.

WHO. (2010). Exposure to Arsenic: A Major Public Health Concern. Geneva: Public Health and Environment; World Health Organization.

Conflict of Interest Statement: The authors declare that the research was conducted in the absence of any commercial or financial relationships that could be construed as a potential conflict of interest.

Received: 09 July 2014; accepted: 03 November 2014; published online: 20 November 2014.

Citation: Bhatia S, Balamurugan G and Baranwal A (2014) High arsenic contamination in drinking water hand-pumps in Khap Tola, West Champaran, Bihar, India. Front. Environ. Sci. 2:49. doi: 10.3389/fenvs.2014.00049

This article was submitted to Environmental Health, a section of the journal Frontiers in Environmental Science.

Copyright (c) 2014 Bhatia, Balamurugan and Baranwal. This is an open-access article distributed under the terms of the Creative Commons Attribution License (CC BY). The use, distribution or reproduction in other forums is permitted, provided the original author(s) or licensor are credited and that the original publication in this journal is cited, in accordance with accepted academic practice. No use, distribution or reproduction is permitted which does not comply with these terms. 